\title{
Improved Prediction of Atmospheric Rivers That Drive Flood Damages in the Western United States
}

\author{
Cary A. Talbot ${ }^{1, a}$, Tom Corringham², F. Martin Ralph ${ }^{2}$, Alexander Gershunov² and Daniel R. Cayan² \\ ${ }^{1}$ Coastal and Hydraulics Laboratory, US Army Corps of Engineers, 3909 Halls Ferry Road, Vicksburg, MS 39180, USA \\ ${ }^{2}$ Center for Western Weather \& Water Extremes, Scripps Institution of Oceanography, 9500 Gillman Drive, La Jolla, CA 92093, USA
}

\begin{abstract}
Atmospheric rivers (ARs) are extratropical storms that produce extreme precipitation on the west coasts of the world's major landmasses and have been shown to be an important source of variations in precipitation and streamflow in the western U.S. and globally. ARs have been identified as the primary source of hydrologic flooding in the western U.S., yet their costs remain largely unquantified. A systematic analysis of 40 years of data from the U.S. National Flood Insurance Program (NFIP) establishes that ARs are the primary drivers of flood damages in the western United States. The NFIP claims and payments are combined with a catalog of ARs classified according to a recently developed AR scale, which varies from category 1 to 5 . The data reveal that flood damages increase exponentially with AR intensity and duration. AR1 and AR2 storms are mostly beneficial, replenishing the water supply while causing median flood damages of less than a million dollars; AR4 and AR5 storms cause median damages in the tens and hundreds of millions of dollars, respectively. A research effort to improve forecast skill of AR landfall and duration has produced an informative set of AR forecast tools. Discussion of these tools along with examples of their use by water resources and emergency management officials is presented.
\end{abstract}

\section{Introduction}

Atmospheric rivers (ARs) are defined in the Glossary of the American Meteorological Society (AMS) (AMS 2017), in part, as "long, narrow and transient corridor(s) of strong horizontal water vapor transport that [are] typically associated with a low-level jet stream ahead of the cold front of an extratropical cyclone. The water vapor in atmospheric rivers is supplied by tropical and/or extratropical moisture sources. Atmospheric rivers frequently lead to heavy precipitation where they are forced upward - for example, by mountains or by ascent in the warm conveyor belt." The definition also states that ARs are "the largest 'rivers' of fresh water on Earth, transporting on average more than double the flow of the Amazon River." Since their early characterization in 1998 using a combination of weather model data (Zhu and Newell, 1998), satellite and aircraft observations (Ralph et al., 2004), ARs have been shown to be an important source of variations in precipitation and streamflow in the western United States (U.S.) and globally (Ralph et al., 2006; Dettinger et al., 2011; Guan and Wallser, 2015). There is growing awareness that ARs are responsible for a wide range of environmental, social and economic impacts, affecting the frequency and severity of extreme floods and influencing drought duration and intensity (Dettinger, 2013). ARs have been identified as the primary source of hydrologic flooding in the western U.S. (Barth et al., 2017;

a Corresponding author: Cary.A.Talbot@usace.army.mil

DOI 10.3311/FLOODRisk2020.17.19
Konrad and Dettinger, 2017). Since sea surface temperature near the coast is a determinant of the amount of rain associated with an AR (Gershunov et al., 2017), quantifying the relationship between AR intensity and economic impact is important, given the rising oceanatmosphere heat content associated with climate change.

A new study has examined 40 years of data from the U.S. National Flood Insurance Program (NFIP) coupled with measures of total damages from a U.S. National Weather Service (NWS) dataset (Downton et al., 2005) and a complete catalog of U.S. west coast landfalling ARs (Gershunov et al., 2017) to provide a comprehensive analysis of flood damages caused by ARs in the western U.S. over the past 40 years (Corringham et al., 2019). Important findings from this study are presented in this paper.

Current research efforts to improve forecast skill of AR landfall location, intensity and duration has produced an informative set of AR forecast tools that are used by water managers and agency decision makers at local, regional and national scales within the U.S. and globally. Discussion of these tools along with examples of their use by water resources and emergency management officials will be presented. 


\section{Method of Analysis}

The analysis used in Corringham et al. (2019) uses both economic loss data from the NFIP and AR data. The sources and method of analysis for each is described in the following sections.

\subsection{Economic data and methods}

Economic loss data is comprised of NFIP daily claims from 1978 to 2017 , with each claim located to the nearest NFIP community (city, typically, or county remainder) and listing the total insured loss to the building and its contents by claim. All monetary values were adjusted to 2018 U.S. dollars (U.S. Bureau of Economic Analysis, 2018). An issue with this data set is that in the western U.S., participation rates in the NFIP are low, even in relatively high-risk areas, making the number of claims and insured losses imperfect measures of total damages.

A comparison of 1983 to 2003 annual NFIP losses to an NWS compilation of economic impacts of flooding (Downton et al., 2005) established that insured losses are a good proxy for overall economic impacts (Fig. 1); the Pearson correlation between the two time series is 0.8 . The NWS data comprise annual total estimated damages due to flooding at the state level from 1983 to 2003, as reported by newspaper articles and the reports of federal agencies. However, the low spatial and temporal resolution of the NWS data render the estimates of total damage using that data set highly imprecise. The measures of insured flood losses from the NFIP, on the other hand, are highly resolved temporally and spatially specific, so they provide a useful source with which to assess the economic impacts of flood events associated with ARs and extreme hydrologic events more generally.

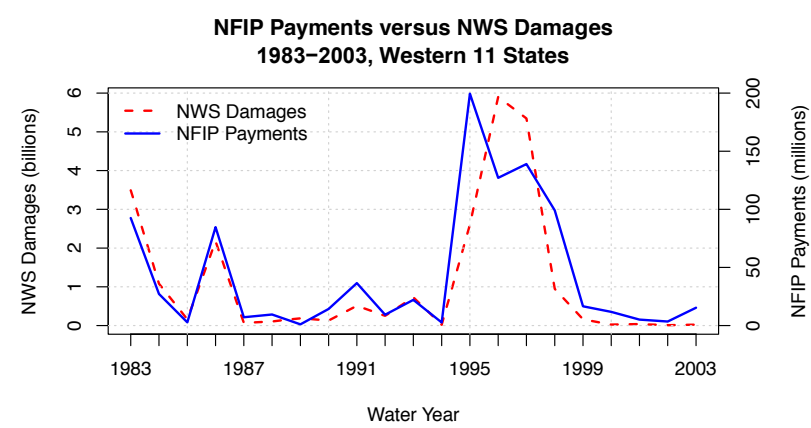

Figure 1. Annual aggregates of NWS damage estimates (dashed red line) and NFIP insured losses (solid blue line).

To analyze the impacts of ARs on insured losses, NFIP loss data and total damage estimates were aggregated spatially over a $2.5^{\circ}$ grid (Fig. 2) and by county (Table 1). Daily claims and insured losses were used throughout, with days defined in local time for the NFIP dataset.

\subsection{Atmospheric river data and methods}

AR data were obtained from Gershunov et al. (2017), who present an AR detection methodology through which they compile a comprehensive catalog of ARs over 70 years using National Center of Environmental PredictionNational Center for Atmospheric Research (NCEPNCAR) reanalysis. This catalog was chosen because of its long duration, its focus on the western United States, and its comparison with independent high-resolution daily precipitation observations.

The Gershunov et al. (2017) catalog identifies the ARs that make landfall along the Pacific coast of North America over a $2.5^{\circ}$ coastal grid. ARs identified were those events whose 6-hour average vertically integrated horizontal vapor transport (IVT) exceeded $250 \mathrm{~kg} \mathrm{~m}^{-1} \mathrm{~s}^{-1}$, along with exceeding prescribed vertically integrated specific humidity and conforming to certain geometric requirements. In addition to time and place of $A R$ occurrences, Gershunov et al. (2017) also provides the zonal and meridional components of IVT and wind at 850 $\mathrm{hPa}$ over a $2.5^{\circ}$ grid of the north Pacific and the western United States at a 6-hour time scale. These data were aggregated to daily resolution in local time using mean and maximal values of the variables by grid cell. If a 6-hour period in a day in local time reached the AR IVT threshold, then it was considered an AR day for this study. This allows direct comparison with daily NFIP flood claims from 1978 to 2017. Corringham et al. (2019) provides additional detail about bias correction that was applied to some IVT values in the NCEP-NCAR reanalysis data.

In the Gershunov et al. (2017) data, there were 1603 events in the 1978-2017 sample (40 per year on average). The durations of daily aggregated events in the sample ranged from 6 hours to 16 days. Median AR duration was 30 hours; mean duration was 40 hours. ARs making landfall from $27.5^{\circ} \mathrm{N}$ to $47.5^{\circ} \mathrm{N}$, that is, over nine $2.5^{\circ}$ latitude bands, are considered (fig. 3). During the course of a multiday event, an AR may make landfall at more than one latitude band. In the sample, ARs were observed making landfall at one to nine separate $2.5^{\circ}$ latitude bands over the course of the event. The mean number of landfalling latitude bands per event was 2.65. The median and modal number of latitude bands was two. The nine coastal grid cells, with arrows indicating the mean IVT direction at landfall, are indicated in fig. 3.

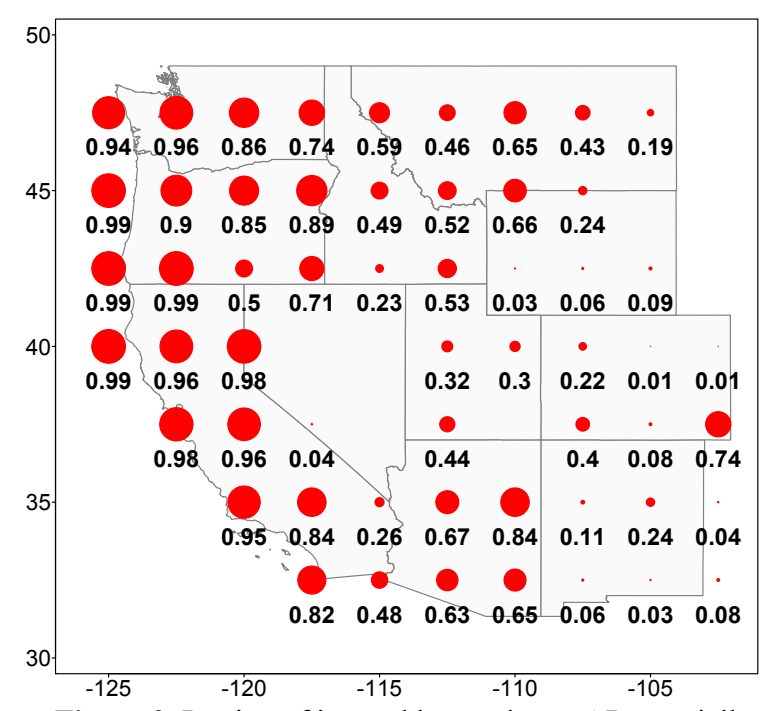

Figure 2. Portion of insured losses due to ARs spatially aggregated to $2.5^{\circ}$ grid in 11 western states in the U.S. 


\begin{tabular}{|c|c|c|c|c|c|}
\hline County & $\begin{array}{l}\text { AR proportion of } \\
\text { insured losses }\end{array}$ & Claims & $\begin{array}{c}\text { Insured losses } \\
(\$ \mathrm{~m})\end{array}$ & $\begin{array}{c}\text { Total damages } \\
(\$ \mathbf{b})\end{array}$ & AR damages (\$b) \\
\hline Sonoma, CA & 0.998 & 6650 & 172.0 & 5.2 & 5.2 \\
\hline Los Angeles, CA & 0.846 & 8280 & 106.1 & 3.2 & 2.7 \\
\hline Lewis, WA & 0.989 & 1979 & 101.4 & 3.0 & 3.0 \\
\hline Marin, CA & 0.987 & 3152 & 73.2 & 2.2 & 2.2 \\
\hline King, WA & 0.970 & 2915 & 69.0 & 2.1 & 2.0 \\
\hline Sacramento, CA & 0.977 & 3609 & 56.9 & 1.7 & 1.7 \\
\hline Snohomish, WA & 0.903 & 1818 & 43.7 & 1.3 & 1.2 \\
\hline Monterey, CA & 0.989 & 1253 & 43.5 & 1.3 & 1.3 \\
\hline Napa, CA & 0.997 & 1331 & 43.2 & 1.3 & 1.3 \\
\hline Washoe, NV & 0.998 & 740 & 42.4 & 1.3 & 1.3 \\
\hline Maricopa, AZ & 0.628 & 2368 & 33.7 & 1.0 & 0.6 \\
\hline Santa Clara, CA & 0.971 & 1557 & 33.4 & 1.0 & 1.0 \\
\hline Clackamas, OR & 0.970 & 730 & 31.5 & 0.9 & 0.9 \\
\hline San Diego, CA & 0.912 & 1945 & 30.7 & 0.9 & 0.8 \\
\hline Orange, CA & 0.899 & 3619 & 29.3 & 0.9 & 0.8 \\
\hline Pierce, WA & 0.974 & 934 & 28.4 & 0.9 & 0.9 \\
\hline Riverside, CA & 0.624 & 1619 & 27.9 & 0.8 & 0.5 \\
\hline Cowlitz, WA & 0.596 & 709 & 26.6 & 0.8 & 0.5 \\
\hline Placer, CA & 0.990 & 598 & 26.5 & 0.8 & 0.8 \\
\hline Columbia, OR & 0.998 & 414 & 24.7 & 0.7 & 0.7 \\
\hline
\end{tabular}

Table 1. Proportion of losses caused by ARs in top 20 counties of 11 western states in the U.S.

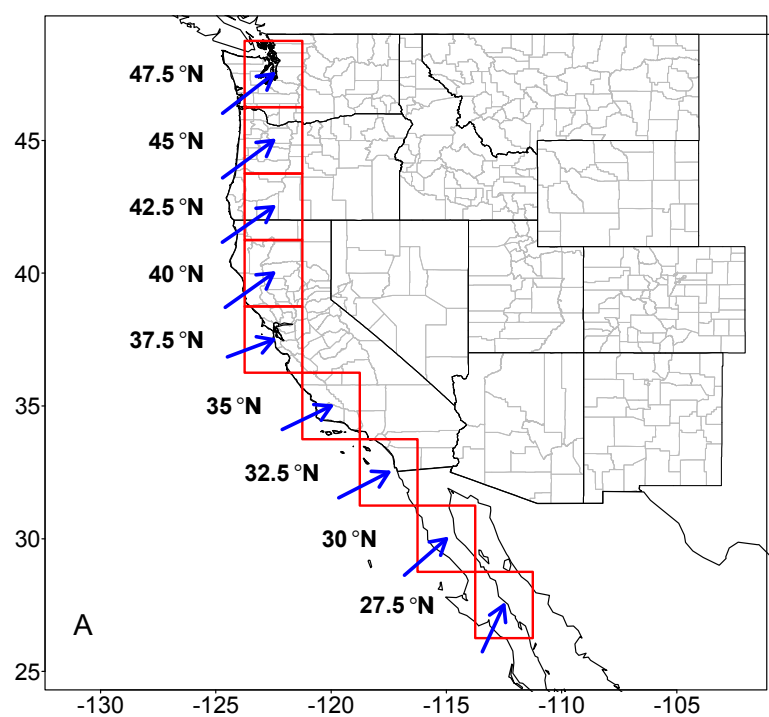

Figure 3. Coastal grid cells with mean IVT direction.

\section{Results of AR economic impact analysis}

Across the 11 western conterminous states, from 1978 to 2017, Corringham et al. (2019) found that total estimated flood damages, during all seasons, amounted to $\$ 50.8$ billion, and ARs accounted for $84 \%$ of these damages, i.e., $\$ 42.6$ billion, or roughly $\$ 1.1$ billion a year. In their study, AR activity is identified by daily maximum 6-hour vertically IVT greater than $250 \mathrm{~kg} \mathrm{~kg} \mathrm{~m}^{-1} \mathrm{~s}^{-1}$, over a string of coastal $2.5^{\circ}$ grid cells (fig. 3), meeting additional geometric and temporal conditions (Gershunov et al., 2017). Over the sample period, 1603 separate ARs made landfall from $27.5^{\circ} \mathrm{N}$ in Baja California to $47.5^{\circ} \mathrm{N}$ in Washington. AR total estimated damages are defined as NFIP-insured losses occurring anywhere in the western United States on the day of or the day following AR conditions, inflated by a factor of 30, which was determined by Corringham and Cayan (2019) in an analysis of NFIP-insured losses against the NWS dataset (Downton et al., 2005) of total damages by state by year over a 21-year period for which both datasets were available (fig. 1). The NWS data are based on information from newspapers; estimates from emergency managers, insurance agents, and local officials; damage assessments by Federal Emergency Management Agency (FEMA) storm survey teams; and crop damage estimates from the U.S. Department of Agriculture. Insurance data were obtained directly from the NFIP.

In the coastal states of California, Oregon, and Washington, the proportions of total insured flood damages attributable to ARs exceeded $99 \%$ in some areas (Fig. 2 and Table 1). Relatively high proportions of damages were associated with AR activity as far east as $100^{\circ} \mathrm{W}$, including much of Arizona, Idaho, and western Montana-inland regions where ARs are known to penetrate (Rutz et al., 2014). Damages in Arizona were due to ARs making landfall in Baja California; damages in Idaho and Montana resulted from inland penetration of ARs through the Columbia River Valley, indicating the importance of the orientation of ARs relative to topography in generating damaging floods (Guirguis et al., 2019). Causes of flood damages in the western United States other than ARs included remnant tropical storms, cutoff low-pressure systems, the North American monsoon, and mesoscale convective systems (Hirschboeck, 1991). These mechanisms resulted in highly damaging events, but their combined impact across the West was surpassed fivefold by the effect of ARs.

Flood damages have been concentrated spatially and temporally. The top 20 counties of the 414 counties of the western United States accounted for $69 \%$ of flood damages over the sample period (Table 1). In these counties, large fractions of damages were associated with AR activity. Proportions were over 0.99 in Sonoma County, which 
experienced the highest damages of the counties over the sample period and is located at the peak of AR land-falling activity along the west coast, in terms of ARs of all intensities (Gershunov et al., 2017; Dettinger et al., 2018). The most affected areas were typically not the most densely populated regions in the western United States, but those with vulnerable assets located near rivers or coastlines prone to significant flooding. Slightly lower but still high proportions of total damages caused by ARs ( 82 to $95 \%$ ) were observed in southern California and the interior Southwest (Fig. 2 and Table 1).

A small number of extreme and exceptional ARs were responsible for a large proportion of total flood damages over the sample period. Only 13 events, spanning 65 days, caused over $\$ 1$ billion in estimated total damages (Table 1). These events accounted for $58.3 \%$ of total insured losses in the sample. These highly damaging ARs were multiday events varying in length from 3 to 11 days, with peak damages generally occurring 1 day after initial landfall. Spatially, the initial crossing latitude ranged from Baja California Norte to Washington, although over the course of many of these multiday events, the storm position over time varied widely from the initial landfall region. The mean orientation of ARs at all latitudes was southwest to northeast, with damages typically occurring to the northeast of landfall. Values of AR intensity as measured by maximum IVT over the course of the events were uniformly high. In most of these highly damaging events, peak IVT was over $750 \mathrm{~kg} \mathrm{~m}^{-1} \mathrm{~s}^{-1}$. The highly impactful New Year's flood of 1996-1997 experienced a very rare exceptional peak IVT of $1260 \mathrm{~kg} \mathrm{~m}^{-1} \mathrm{~s}^{-1}$ (Table 2).

\begin{tabular}{|c|c|c|c|c|c|c|c|}
\hline Start date & $\begin{array}{l}\text { Initial landfall } \\
\text { region }\end{array}$ & $\begin{array}{c}\text { Initial } \\
\text { landfall } \\
\text { latitude }\end{array}$ & $\begin{array}{c}\text { AR } \\
\text { category }\end{array}$ & $\begin{array}{l}\text { Peak IVT (kg } \\
\left.\qquad \mathrm{m}^{-1} \mathrm{~s}^{-1}\right)\end{array}$ & Claims & $\begin{array}{c}\text { Insured } \\
\text { losses } \\
(\$ \mathrm{~m})\end{array}$ & $\begin{array}{c}\text { Total } \\
\text { damages } \\
(\$ b)\end{array}$ \\
\hline 4 January 1995 & S. California & $32.5^{\circ} \mathrm{N}$ & 4 & 966 & 4725 & 125.8 & 3.7 \\
\hline 29 December 2005 & N. California & $40^{\circ} \mathrm{N}$ & 4 & 825 & 2554 & 117.6 & 3.5 \\
\hline 29 December 1996 & Central California & $35^{\circ} \mathrm{N}$ & 5 & 1260 & 3407 & 104.6 & 3.1 \\
\hline 5 February 1996 & N. Oregon & $45^{\circ} \mathrm{N}$ & 3 & 729 & 2695 & 99.3 & 3.0 \\
\hline 2 December 2007 & N. Oregon & $45^{\circ} \mathrm{N}$ & 5 & 1258 & 1447 & 83.9 & 2.5 \\
\hline 15 February 1986 & Washington & $47.5^{\circ} \mathrm{N}$ & 4 & 870 & 2048 & 66.6 & 2.0 \\
\hline 7 March 1995 & S. Oregon & $42.5^{\circ} \mathrm{N}$ & 4 & 928 & 2343 & 58.7 & 1.8 \\
\hline 5 January 2009 & S. Oregon & $42.5^{\circ} \mathrm{N}$ & 4 & 831 & 1636 & 53.9 & 1.6 \\
\hline 1 February 1998 & Central California & $37.5^{\circ} \mathrm{N}$ & 4 & 795 & 2417 & 46.8 & 1.4 \\
\hline 1 November 2006 & N. California & $40^{\circ} \mathrm{N}$ & 5 & 1041 & 1184 & 38.7 & 1.2 \\
\hline 25 January 1983 & Central California & $37.5^{\circ} \mathrm{N}$ & 5 & 1013 & 1545 & 34.9 & 1.0 \\
\hline 25 February 1983 & Central California & $37.5^{\circ} \mathrm{N}$ & 3 & 658 & 1832 & 30.0 & 0.9 \\
\hline 12 February 1980 & Baja, Mexico & $30^{\circ} \mathrm{N}$ & 3 & 525 & 2059 & 28.5 & 0.9 \\
\hline 3 January 1982 & N. California & $40^{\circ} \mathrm{N}$ & 3 & 525 & 1422 & 28.1 & 0.8 \\
\hline 11 February 1986 & N. California & $40^{\circ} \mathrm{N}$ & 4 & 904 & 848 & 23.9 & 0.7 \\
\hline 21 November 1990 & Washington & $47.5^{\circ} \mathrm{N}$ & 4 & 943 & 939 & 23.3 & 0.7 \\
\hline
\end{tabular}

Table 2. Most damaging atmospheric rivers 1978-2017 in the western U.S.

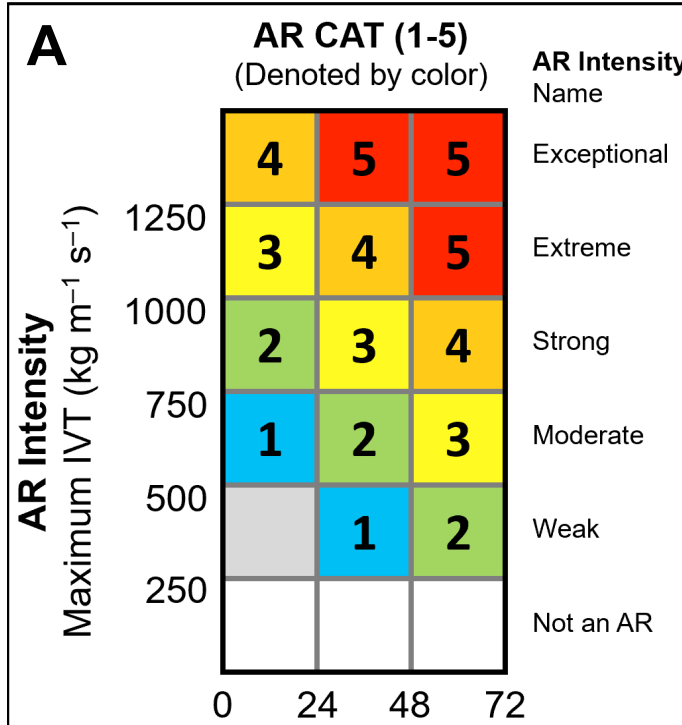

AR Duration (IVT > 250) (h)
B

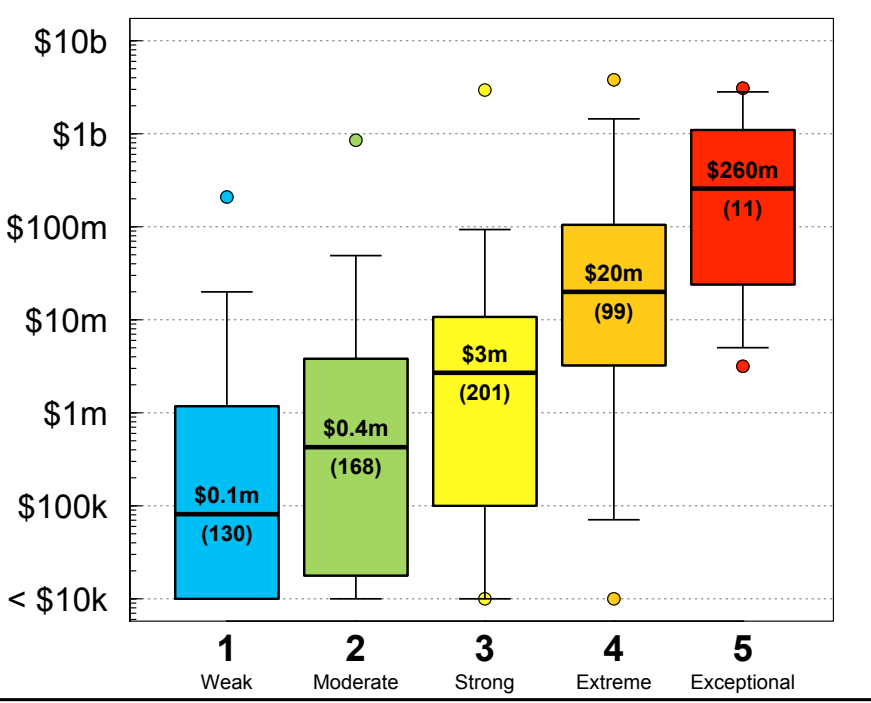

Figure 4. (A) The Ralph et al. (2019) AR scale classifies ARs into five categories depending on IVT and duration. For example, an AR with a peak IVT of $800 \mathrm{~kg} \mathrm{~m}^{-1} \mathrm{~s}^{-1}$ and a duration of 78 hours is classified as a category 4 or extreme AR. (B) NDJFM flood damages increase exponentially with AR category: Vertical scale is logarithmic; black bars are medians; boxes are 25th and 75th percentiles, and whiskers are 5th and 95th percentiles; dots are extrema; numbers in parentheses are the number of NDJFM events in each category. Note that the total number of ARs in the Gershunov AR catalog (1603) is greater than the number of ARs over the sample period using the Ralph et al. AR scale (1134), which classifies events with a duration of less than 24 hours as non-ARs. 


\begin{tabular}{lcccccccc}
\hline AR Category & $\begin{array}{c}\text { Number } \\
\text { of events }\end{array}$ & $\begin{array}{c}\text { Minimum } \\
\mathbf{( \$ m )}\end{array}$ & $\begin{array}{c}\mathbf{5 \%} \\
\mathbf{( \$ m )}\end{array}$ & $\begin{array}{c}\mathbf{2 5 \%} \\
\mathbf{( \$ m )}\end{array}$ & $\begin{array}{c}\text { Median } \\
\mathbf{( \$ m )}\end{array}$ & $\begin{array}{c}\mathbf{7 5 \%} \\
\mathbf{( \$ m )}\end{array}$ & $\begin{array}{c}\mathbf{9 5 \%} \\
\mathbf{( \$ m )}\end{array}$ & $\begin{array}{c}\text { Maximum } \\
\mathbf{( \$ m )}\end{array}$ \\
\hline CAT 1 & 130 & 0 & 0 & 0 & 0.1 & 1 & 24 & 208 \\
\hline CAT 2 & 168 & 0 & 0 & 0 & 0.3 & 4 & 48 & 844 \\
\hline CAT 3 & 201 & 0 & 0 & 0.1 & 2 & 10 & 94 & 2930 \\
\hline CAT 4 & 99 & 0 & 0.1 & 3 & 19 & 85 & 1424 & 3773 \\
\hline CAT 5 & 11 & 3 & 5 & 24 & 259 & 1102 & 2821 & 3126 \\
\hline All ARs & 609 & 0 & 0 & 0 & 2 & 10 & 197 & 3773 \\
\hline
\end{tabular}

Table 3. Summary statistics of damages by atmospheric river category, November to March, in millions of dollars. Damages under $\$ 50,000$ are rounded down to $\$ 0$.

A recently developed scale of AR intensity (Ralph et al., 2019) similar to scales for hurricanes and tornadoes captures a range of AR effects, classifying ARs from category 1 to 5 . The scheme (Fig. 4A) categorizes ARs based on peak IVT in increments of $250 \mathrm{~kg} \mathrm{~m}^{-1} \mathrm{~s}^{-1}$ and then adjusts the category based on the duration of the event. Although some ARs cause significant damage, most are largely beneficial. ARs are known to generate much of the annual precipitation in California and the western United States, replenishing the region's water supply (Dettinger, 2013), and the insurance record reveals that about half (801) of all ARs in the sample caused no insured losses.

Effects of ARs by category are posited to range from mostly beneficial (categories 1 and 2: short duration, low IVT) to mostly damaging (categories 4 and 5: long duration, high IVT). An examination of November to March (NDJFM) flood damages supports these assertions (Fig. 4B and Table 3). Category 1 and 2 storms caused negligible median damages of under $\$ 1$ million, while category 4 and 5 storms caused significant median damages in the tens and hundreds of millions of dollars over the study period of 1978 to 2017 during the AR damage season (NDJFM). Notably, with each increase in AR category, 2 and above, median damages increased roughly by an order of magnitude. Thus, increases in AR duration and intensity led to exponential increases in flood damages.

While the AR scale corresponds well to insured flood losses and estimated total damages, there was significant variability in damages within each category. Beyond peak IVT and duration, several other factors were important determinants of AR-related flood damages. For example, the two least damaging category 5 storms $(11$ November 1983 at $42.5^{\circ} \mathrm{N}$ and 29 November 2007 at $27.5^{\circ} \mathrm{N}$ ) affected sparsely populated areas early in the wet season when soils were still dry and able to absorb most of the extreme precipitation, causing less than $\$ 10$ million in damages. In contrast, the most damaging category 1 storm occurred 2 weeks after the devastating 1996-1997 New Year's flood in northern California and western Nevada when soils and snowpack were primed for high runoff and river stages were already at high levels (Hammond and Harmon, 1998), causing over $\$ 200$ million in damages.

\section{Research to improve AR forecast skill}

Improved prediction of AR frequency and intensity, as well as latitude of landfall and duration of individual $\mathrm{AR}$ events, in near-term and at subseasonal-to-seasonal time scales could provide significant increases in the efficiency of water operations at reservoirs by achieving simultaneous improvements in both water conservation and flood management through forecast informed reservoir operations. These improvements could be realized without costly and time-consuming structural modifications. Benefits to emergency management officials could also be realized through more effective prepositioning of resources and use of evacuation measures.

\subsection{Forecast informed reservoir operations}

To this end, a collaborative research effort between elements of the U.S. National Oceanographic and Atmospheric Administration (NOAA), U.S. Bureau of Reclamation (USBOR), U.S. Fish and Wildlife Service (USFWS), U.S. Army Corps of Engineers (USACE), various state and local water agencies and academic partners at the Center for Western Weather and Water Extremes (CW3E) has been has been underway since 2014. This effort, known as Forecast Informed Reservoir Operations (FIRO), has the aim of improving forecast skill for prediction of atmospheric river events and exploring the incorporation of forecast information into water management operations in a safe and effective fashion to simultaneously improve water supply reliability, flood risk management and ecosystem benefits.

FIRO efforts are guided by multi-disciplinary, multiagency steering committees with scientists, engineers, and operations professionals from key stakeholders concerned with operations, flood risk management and regulatory issues at pilot reservoirs where FIRO is being developed and tested. Work plans are developed by the steering committees that lay out a process of preliminary and full viability assessments to test the applicability and transferability of FIRO principles at each pilot reservoir (CW3E, 2020a).

\subsection{AR forecast tools}

Atmospheric scientists participating in FIRO have developed numerous forecast tools that are currently used by water operations officials at FIRO pilot reservoirs as well as by water resources decision-makers at reservoirs in the western U.S. and across the country. Some of these tools are used within a decision support system (DSS) specifically designed for use at Lake Mendocino, the first FIRO pilot reservoir located in the Russian River watershed in northern California. A schematic of the Russian River DSS is shown in Figure 5. 


\section{FIRO Decision Support System}

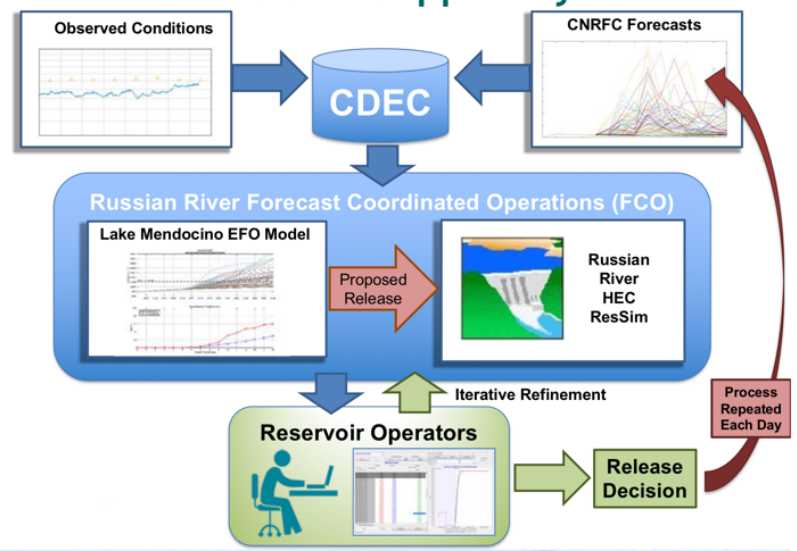

Figure 5. Russian River FIRO Decision Support System.

Observed conditions from a network of gages, sensors and weather stations in the watershed are fed into the California Data Exchange Center (CDEC) where they are coupled with reservoir inflow forecasts from the NWS California-Nevada River Forecast Center (CNRFC). The heart of the Russian River FIRO DSS is the Russian River Forecast Coordinated Operations (FCO) tool where model results from the Lake Mendocino Ensemble Forecast Operations (EFO) Model (Delaney et al., 2020) are used by the reservoir operators to make proposed release decisions. Those proposed releases are then run through a USACE Hydrologic Engineering Center (HEC) Reservoir Simulation (ResSim) model to determine downstream impacts to water supply, flood risk and ecologic benefits from the proposed release. This process is iterative as various proposed releasaes can be tested as downstream impacts from each are evaluated. The DSS enables the operators to optimally select the best release decision based on the modelled outcomes.

More general AR forecast products are made available at CW3E's atmospheric river forecast products web site (CW3E, 2020b). There interested parties can chose from among numerous atmospheric river forecast products, including twice daily updated deterministic model results for integrated water vapor (IWV) and integrated vapor transport (IVT) from two different global atmospheric models: the NCEP Global Forecast System (GFS), and the North American Mesoscale Forecast System (NAM). These model results are presented graphically for various regions of interest: North Pacific, Northeast Pacific, U.S. West Coast, North America and North Atlantic (fig. 6). Any one of these regions can be selected to view forecast results in 3-hour interpolated increments out to 180 hours (in the case of the GFS) or 84 hours (in the case of the NAM).

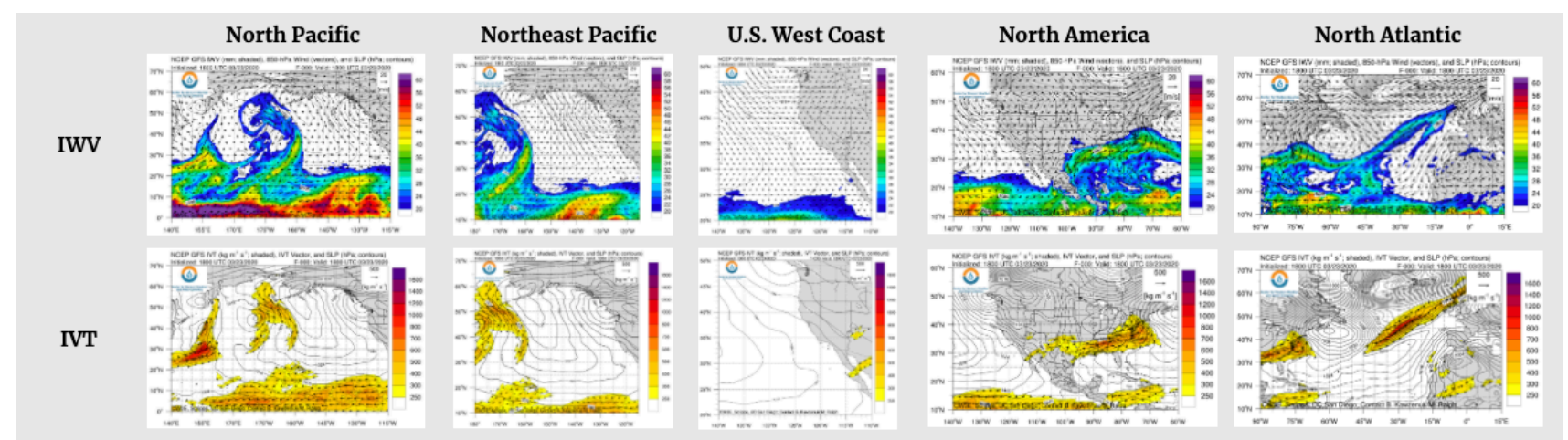

Figure 6. Graphical IWV and IVT forecast products for various regions available on the CW3E AR forecast tools website.

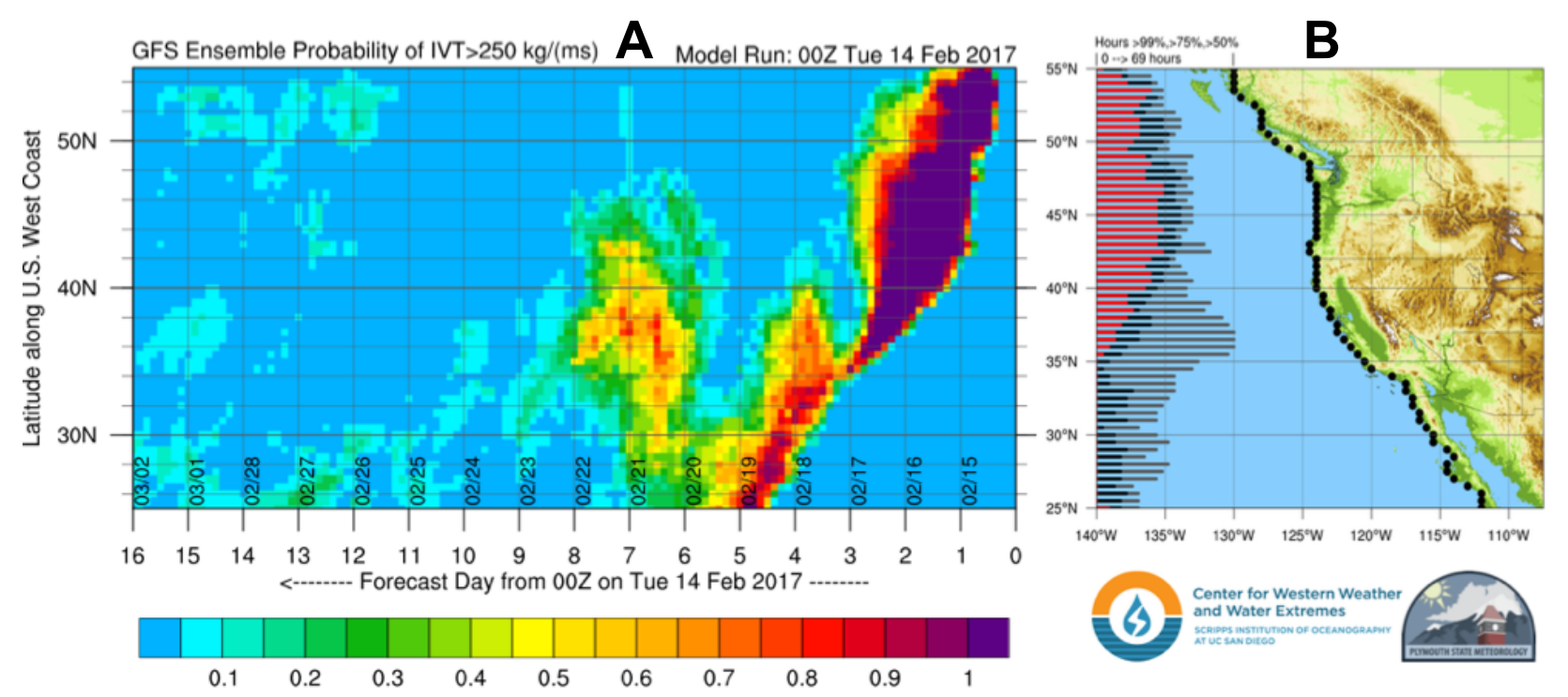

Figure 7. (A) West Coast AR Landfall Tool depicting probability of IVT $>250 \mathrm{~kg} \mathrm{~m}^{-1} \mathrm{~s}^{-1}$ conditions for 16 days starting from 14 Feb. 2017 based on 20-member GFES for (B) coastal locations (black dots) of North American from $25^{\circ} \mathrm{N}$ to $55^{\circ} \mathrm{N}$ at $0.5^{\circ}$ intervals. 
Of particular interest to water managers in the western U.S. is another tool available at CW3E's atmospheric river forecast products page, the West Coast AR Landfall Tool (Fig. 7). This tool displays the likelihood and timing of AR conditions at each point on the map (Fig. 7b) in a line along the North American West Coast or inland as derived from either the NCEP Global Ensemble Forecast System (GEFS) model or the European Centre for Medium Range Weather Forecast (ECMWF) model over the next 7 or 16 days. The probability of AR conditions represents the number of ensemble members (20 in total) that predict IVT to be greater than the chosen threshold at the given location and time. The AR Landfall Tool can be viewed statically or temporally to observe how the forecast has changed over the previous seven days which helps operators to understand the relative forecast consistency over time for an approaching storm.

Companion products to the West Coast AR Landfall Tool are the West Coast IVT Plume Diagrams. The plume diagrams represent the IVT magnitude forecast for each of the 20 perturbed GFS or ECMWF models, the unperturbed GFS or ECMWF control forecast, the 20-member ensemble mean and the $+1 /-1$ standard deviation values of the ensemble for any coastal location at $0.5^{\circ}$ intervals from $25^{\circ} \mathrm{N}$ to $55^{\circ} \mathrm{N}$ along the North American West Coast. An example plume diagram is shown in Figure 8. These diagrams give operators a sense of the spread in ensemble member forecasts of AR strength and duration over time at a given location. The greater spread between ensemble members, the greater the uncertainty in the forecast whereas small spread indicates good confidence in forecasted AR strength and duration.

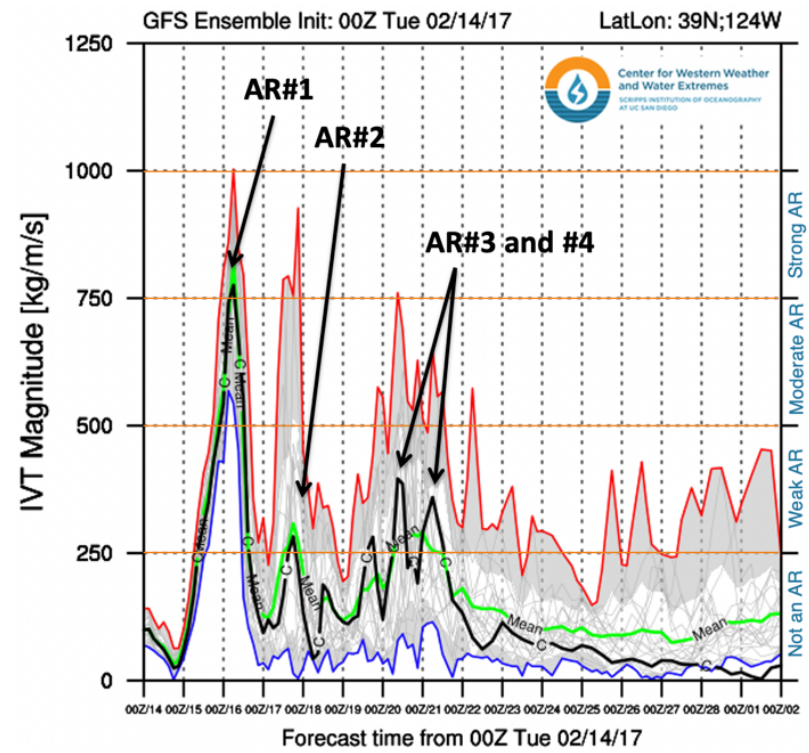

Figure 8. West Coast IVT GEFS Plume Diagram for $39^{\circ} \mathrm{N}$; $124^{\circ} \mathrm{W}$ starting at $14 \mathrm{Feb} .2017$. The red and blue lines indicate the +1 and -1 standard deviation values of the 20 -member forecast, respectively. The thick black line depicts the unperturbed GFS control forecast and the green line the 20member ensemble mean. The tight agreement between the forecasts for AR\#1 indicates good confidence in the forecast strength at this location while the large spread for AR's \#2-4 indicate less confidence in the forecast for this location.

\section{Conclusions}

The analysis presented in Corringham et al. (2019) shows that modest increases in AR intensity could lead to significant increases in flood damages. The increase in exposure to risk over the coming decades, as population in the western coastal states continues to grow, is likely to drive damages even higher. As ARs increase in intensity with a warmer climate, becoming wetter, longer and wider (Espinoza et al., 2018), the need for understanding the correlation between the duration and intensity of ARs and economic damages that can result will be important for flood plain managers, emergency management officials and engineers and planners tasked with providing flood protection and risk management into the future.

The AR forecast tools being developed and produced from the research efforts like FIRO are providing water management professionals with an increased ability to make proactive water resources decisions. Having increased understanding of the atmospheric phenomena that drive floods and increased confidence in forecasts of ARs can allow water management officials to make forecast informed operational decisions that can increase the reliability of water supply while also increasing flood risk management and ecosystem benefits.

\section{Acknowledgement}

Permission was granted by the Chief of Engineers, USACE to publish this information.

\section{References}

1. American Meteorological Society, 2017: Atmospheric river. Glossary of Meteorology, http://glossary.ametsoc.org/wiki/Atmospheric_river.

2. Barth, N. A., G. Villarini, M. A. Nayak and K. White, (2017). Mixed populations and annual flood frequency estimates in the western United States: The role of atmospheric rivers. Water Resour. Res. 53, 257-269.

3. Center for Western Weather and Water Extremes, (2020a). Forecast Informed Reservoir Operations, https://cw3e.ucsd.edu/firo/.

4. Center for Western Weather and Water Extremes, (2020b). Forecast Informed Reservoir Operations, https://cw3e.ucsd.edu/ iwv-and-ivt-forecasts/.

5. Corringham, T. W. and D. R. Cayan, (2019). The effect of El Niño on flood damages in the western United States. Wea. Climate Soc. 11, 489-504.

6. Corringham, T. W., F. M. Ralph, A. Gershunov, D. R. Cayan and C. A. Talbot, (2019). Atmospheric rivers drive flood damages in the western United States. Sci. $A d v$. 5, eaax 4631 .

7. Delaney, C. J., J. Mendoza, J. Jasperse, R. K. Hartman, F. M. Ralph, L. D. Monache and C. A. Talbot, (2020). Forecast Informed Reservoir Operations Using Ensemble Streamflow Predictions for a Multi-Purpose Reservoir in Northern California. Water Resour. Res. (in publication). 
8. Dettinger, M. D., F. M. Ralph, T. Das, P. J. Neiman and D. R. Cayan, (2011). Atmospheric rivers, floods and the water resources of California. Water 3, 445478.

9. Dettinger, M. D., (2013). Atmospheric rivers as drought busters on the U.S. West Coast. $J$. Hydrometeorol. 14, 1721-1732.

10. Dettinger, M. D., F. M. Ralph and J. J. Rutz, (2018). Empirical return periods of the most intense vapor transports during historical atmospheric river landfalls on the U.S. West Coast. J. Hydrometeorol. 19, 13631377.

11. Downton, M. W., J. Z. Barnard Miller and R. A. Pielke Jr., (2005). Reanalysis of U.S. national weather service flood loss database. Nat. Haz. Rev. 6, 13-22.

12. Espinoza, V., D. E. Waliser, B. Guan, D. A. Lavers and F. M. Ralph, (2018). Global analysis of climate change projection effects on atmospheric rivers. Geophys. Res. Lett. 45, 4299-4308.

13. Gershunov, A., T. Shulgina, F. M. Ralph, D. A. Lavers and J. J. Rutz, (2017). Assessing the climatescale variability of atmospheric rivers affecting western North America. Geophys. Res. Lett. 44, 7900-7908.

14. Guan, B. and D. E. Waliser, (2015). Detection of atmospheric rivers: Evaluation and application of an algorithm for global studies. J. Geophys. Res. Atmos. 120, 12514-12535.

15. Guirguis, K. A., A. Gershunov, T. M. Shulgina, R. E. S. Clemesha and F. M. Ralph, (2019). Atmospheric rivers impacting Northern California and their modulation by a variable climate. Clim. Dyn. 52, 6569-6583.

16. Hammond, S. E. and J. G. Harmon, (1998). Publications Document: Floods of January 1997 in California and Nevada, USGS Fact Sheet FS-093-98.

17. Hirschboeck, K. K., (1991). Hydrology of Floods and Droughts, Climate and Floods, USGS Water Supply Paper 237.

18. Konrad, C. P. and M. D. Dettinger, (2017). Flood runoff in relation to water vapor transport by atmospheric rivers over the western United States, 1949-2015. Geophys. Res. Lett. 44, 11,456-11,462.

19. Ralph, F. M., P. J. Neiman and G. A. Wick (2004). Satellite and CALJET aircraft observations of atmospheric rivers over the eastern North Pacific Ocean during the winter of 1997/98. Mon. Wea. Rev. 132, 1721-1745.

20. Ralph, F. M., P. J. Neiman, G. A. Wick, S. I. Gutman, M. D. Dettinger, D. R. Cayan and A. B. White, (2006). Flooding on California's Russian river: Role of atmospheric rivers. Geophys. Res. Lett. 33, L13801.

21. Ralph, F. M., J. J. Rutz, J. M. Cordeira, M. Dettinger, M. Anderson, D. Reynolds, L. J. Schick and C. Smallcomb, (2019). A scale to characterize the strength and impacts of atmospheric rivers. Bull. Amer. Meteor. Soc. 100, 269-289.

22. Rutz, J. J., W. J. Steenburgh and F. M. Ralph, (2014). Climatological characteristics of atmospheric rivers and their inland penetration over the western United States. Mon. Wea. Rev. 142, 905-921.
23. U.S. Bureau of Economic Analysis, (2018). Gross Domestic Product: Table 1.1.3. Real Gross Domestic Product, Quantity Indexes, U.S. Bureau of Economic Analysis.

24. Zhu, Y. and R. E. Newell (1998). A proposed algorithm for moisture fluxes from atmospheric rivers. Mon. Wea. Rev. 126, 725-735. 